\begin{tabular}{|c|c|}
\hline \multirow{3}{*}{ 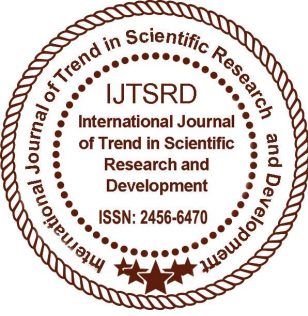 } & $\begin{array}{l}\text { International Journal of Trend in Scientific } \\
\text { Research and Development (IJTSRD) }\end{array}$ \\
\hline & International Open Access Journal \\
\hline & ISSN No: 2456 - 6470 | www.ijtsrd.com | Volume - 2 | Issue - 4 \\
\hline
\end{tabular}

\title{
A Review of Cleanliness Mission "Swachh Bharat Abhiyan"- A Survey done for Thane District
}

\author{
Supreeta Desai, Prof. Sudeshna Roy \\ MCA Department, Bharati Vidyapeeth Instittute of Information Technology and Management, \\ CBD Belapur, Navi Mumbai, Maharashtra, India
}

\begin{abstract}
Living within the lap of nature is an ecstasy. The need of the hour is to conserve and safeguard the aura and ecological life balance of nature. This menace may be fought against solely by creating awareness in the society.
\end{abstract}

"Cleaning and organizing is a practice and not a project"

Swachh Bharat Abhiyan is a mission towards protecting our environment from getting filthy. It was a major step taken by the Government of India and the objective is to eliminate open defection, conversion of insanitary toilets to pour flush toilets and eradication of manual scavenging. Cooperation of people is mandatory to make Swachh Bharat Abhiyan mission successful.

The dusty and stained walls have been transformed into beautiful art piece like that of thane station area. The dump yard which was filled with garbage and of course the unbearable stink have been cleaned. The garbage which was overflowing has been picked up. On the other hand there are residents with poor hygiene which needs to be improved. People talk about litter around them but are not taking any measures to dispose it. It should not just be the responsibility of the 'safaai kaamgar' who clean the particular area.

Keywords: Swachh Bharat Abhiyan, Swachh Bharat Mission, Swachhata Abhiyan,Clean India, Swachh Bharat Abhiyan Clean India

\section{INTRODUCTION}

Mahatma Gandhi was a Prodigious person in the life of every individual in India, whatever Gandhji had uncovered has timeless dimension to it. The ideas are concerning even more so today. His vision was clear cut: a clean mind, a clean body and clean surroundings.

Back in 1999 the government had structured the gramin sanitation program and launched "Nirmal Bharat Abhiyan" which was so not recognized by people of India and was unsuccessful to achieve its target. However failure had its drawbacks as the campaign had minimal people participation and the awareness level was very low.

On $2^{\text {nd }}$ October 2014 our prime minister Narendra Modi launched "Swacch Bharat Abhiyan" campaign in India which aims to eliminate open defecation through construction of household owned and community owned toilets. Nirmal Bharat Abhiyan was wholly and solely had its focus on open defecation whereas now Swacch Bharat Abhiyan have addressed the drawbacks.

India has evolved on many fronts like Business, science and technology, Cloud architect, Health science and many more over the decades since independence in 1947. Our per capita income has been rising at current prices during 2017-18 is estimated to have attained a level of Rs $1,12,835$ as compared to the estimates for the year 2016-17 of Rs $1,03,870$, showing a rise of 8.6 percent . Today the literacy rate in India has been improved a lot; the most literate state is Kerala with $93.92 \%$. However, on the 
Contrary, India has the largest numbers of malnourished people in the world. Studies show that malnourishment is not only lack of proper nutrition but also access to hygiene, safe drinking water and food. Many water related diseases like cholera, diarrhea, malaria, typhoid and filariasis erupt every year in India due to poor quality drinking water and sanitation. Access to safe water and sanitation are crucial for a healthier lifestyle.

India's 1.32 billion people live in large number of rural as well as urban habitations. The cities such as Mumbai, Bangalore, Delhi, Ahmadabad and Hyderabad are considers as the most populated cities in India. The population density is around 412 people per square kilometer, which ranks 31 st in the world. Around $70 \%$ of India's population live in rural area so about one-third population i.e. $30 \%$ population live in urban area. So looking at the statistics we need to determine the sanitation program differently in both the rural as well as urban area.

\section{LITRATURE SURVEY:}

\section{List of facilities provided by swachhata abhiyan.}

As of today Swachh Bharat Abhiyan has cover more than 7.5 crore households, 3.8 lakh open defecation free villages, more than 4,465 open defecation free villages in namami gange, 395 open defecation free districts and 17 open defecation free states/UTs as of June 2018.

\section{A. Swachh bharat mission (Urban area)}

The mission had its precedence i.e. to bring behavioral changes in people regarding healthy and hygienic lifestyle, eliminating solid waste and scavenging, conversion of unsanitary toilets to pour flush toilets and completely eradicating open defecation. Public toilets have been build in various location around like the bus stops, railway stations, tourist places, markets and also in slum areas the government is progressively planning to build more toilets. Rs 4000/- is given to every household for construction of a toilet by the government of India where 2000/- will is given as first installment after verification and 2000/- will be given after under construction toilet photographs are sent as a proof to ministry, additionally, 1300 per household will be given as an incentive. Swachh Bharat for Urban area has constructed around 34 lakh toilets.
According to the guidelines of Swachh Bharat Mission (Urban) tentative basic cost for community toilets is Rs. 65,000/- per seat which has been revised with additionally Rs. 39,200/- per seat and for public toilets is Rs. 75,000/- per seat which has been revised with additionally Rs. 12,800/- per seat.

B. Swachh bharat mission (Gramin or Rural area) Nirmal bharat abhiyan which was initially called as total sanitation campaign was planned to make india an open defecation free in gramin area through proper management of solid and liquid waste.Swachh bharat gramin has build over 5.3 crore toilets. In rural India, 3.8 lakh villages, have been declared open defecationfree.

Swachh bharat gramin has been allocated Rs.13,948 crore in 2017-2018. Total Rs.10,000-Rs.12,000 per unit fund allocation has been given for rural toilets and Rs.35,000 has be given for school toilets. For anganwadi toilets, the funds provided is Rs. 8,000 and community toilets is Rs.2 lakh. The mission is been carried out with involvement of every gram panchayat i.e. village council, panchayat samiti and Zila parishad. Also school Children and teachers have put efforts in making this mission successful. The main Mission is to contribute in construction of individual household latrine in rural development.

\section{Promotion or advertisement.}

Bollywood celebrities play powerful impact on today's youth. The government of India hence collaborated with several celebrities for this purpose with an intent to carry out an Open-Defecation Free (ODF) India by 2 October 2019. Various personalities who have promoted the cause include Amitabh Bachchan, Anushka Sharma, Shilpa Shetty, Virat Kohli, Priyanka Chopra, Sachin Tendulkar and Salman Khan. While some of these personalities like vidya balan, Amitabh Bachchan featured in the ad campaigns; others were seen encouraging the motive by picking a broom. Around Rs 530 crore was spent for the marketing the Swachh Bharat Abhiyaan in three years.

\section{NGO's which promotes swachhata abhiyan.}

The NGO's are the non-governmental organizations who work independently of any government whose whole idea is to handle issues that are either social or political. Various NGO's like SWaCH pune(Solid Waste Collection and Handling), The Ugly Indian and Waste warriors. 


\section{III.OBJECTIVE:}

1. To understand and identify the programs or facilities by government through swacchata abhiyan.

2. To know the awareness of facilities.

3. To identify the use of facilities.

\section{Research Questionnaire:}

Thane made a forward leap from 116 to 40 according to a recent article by times of India.

\begin{tabular}{|c|c|c|}
\hline Sr No. & Questions & Options \\
\hline 1. & Are you aware of the Nirmal Bharat Abhiyan? & $\begin{array}{l}\text { 1. yes } \\
\text { 2. no }\end{array}$ \\
\hline 2. & Are you aware of the Swachh Bharat Abhiyan? & $\begin{array}{l}\text { 1. yes } \\
\text { 2. no }\end{array}$ \\
\hline 3. & $\begin{array}{l}\text { Are you interested in contributing to the Swachh Bharat } \\
\text { Abhiyan }\end{array}$ & $\begin{array}{ll}\text { 1. } & \text { Strongly Disagree } \\
\text { 2. } & \text { Disagree } \\
\text { 3. } & \text { Neutral } \\
\text { 4. } & \text { Agree } \\
\text { 5. } & \text { Strongly Agree }\end{array}$ \\
\hline 4. & Is 24 hour water available in /for the toilet? & $\begin{array}{l}\text { 1.yes } \\
\text { 2.no } \\
\text { 3.sometimes } \\
\end{array}$ \\
\hline 5. & Do you prefer using Public Toilet? & $\begin{array}{l}\text { 1.yes } \\
\text { 2.no }\end{array}$ \\
\hline 6. & $\begin{array}{l}\text { Is there any Open Defecation spot /excreta in an open } \\
\text { place? }\end{array}$ & $\begin{array}{l}\text { 1.yes } \\
\text { 2.no }\end{array}$ \\
\hline 7. & $\begin{array}{l}\text { Do you still find plastic being used at around you in } \\
\text { market instead of a eco friendly bag }\end{array}$ & $\begin{array}{l}\text { 1.yes } \\
\text { 2.no }\end{array}$ \\
\hline 8. & Are you using plastic bags instead of eco friendly bags ? & $\begin{array}{l}\text { 1.yes } \\
\text { 2.no }\end{array}$ \\
\hline 9. & Do you know about the Swachh Bharat Abhiyan app? & $\begin{array}{l}\text { 1. yes } \\
\text { 2. no } \\
\text { 3. no idea }\end{array}$ \\
\hline 10. & Have you used the Swachh Bharat Abhiyan app? & $\begin{array}{l}\text { 1. yes } \\
\text { 2. no } \\
\text { 3. no idea }\end{array}$ \\
\hline 11. & $\begin{array}{l}\text { Do you think that hoarding and advertisment are enough } \\
\text { to spread the awarness about Swachh Bharat Abhiyan? }\end{array}$ & $\begin{array}{l}\text { 1. yes } \\
\text { 2. no }\end{array}$ \\
\hline 12. & Do you know about wet or dry garbage & $\begin{array}{l}\text { 1. yes } \\
\text { 2. no } \\
\text { 3. no idea }\end{array}$ \\
\hline 13. & At home do you maintain separate Wet and Dry Garbage? & $\begin{array}{l}\text { 1. yes } \\
\text { 2. no } \\
\text { 3. no idea }\end{array}$ \\
\hline 14. & Do you find less littering on road? & $\begin{array}{l}\text { 1. yes } \\
\text { 2. no } \\
\text { 3. no idea }\end{array}$ \\
\hline 15. & $\begin{array}{l}\text { In your perception would the swatch Bharat Abhiyan } \\
\text { change the mindset of the people? }\end{array}$ & $\begin{array}{l}\text { 1. yes } \\
\text { 2. no } \\
\text { 3. no idea }\end{array}$ \\
\hline 16. & Rate the cleanliness of the public toilets in your area & 1 to 5 \\
\hline
\end{tabular}




\section{RESEARCH METHODOLOGY:}

Primary Data:

Survey forms are distributed to the local residents of thane for data collection. Survey forms contain Questionnaire. The reasons were:

1. To determine whether or not the queries chosen are going to be relevant in addressing the set objectives of the analysis and conjointly to update form and discard pointless queries.

2. To rectify errors before the specific questionnaires go out to the particular respondents.

3. To calculate the intermediate response rate within the use of numerous medium for information collection.

We have prepared semi-open ended questions. These questions allocated have no restrictions on how research participants could respond to the questions. Participants reply to the given questionnaire according to their own opinion with closed ended questions.

Secondary Data:

$>$ Secondary research methodology defined as Data which were gathered from miscellaneous sources, inclusive of reference materials like dictionaries, archival sources, textbooks, journals/articles, review and online sites.

In secondary research methodology, we have refer various application on the playstore listed below:

1. Swachhata-MoHUA

2. Swachh Bharat Abhiyaan

3. Swachh Bharat Clean India App

4. My Clean India

Also, Radio stations and TV channels promote 'swachhta hi seva' campaign.

\section{Sample Size}

The population under-study which consists of local residents in thane district of 18.9 lakhs as of july 2018, it is remarkably impossible to interview such chaotic amount of population. So a part of population is referred as sample for the survey. 51 members from Lodha Paradise in Thane district were surveyed which included 23 female and 28 male.
VII. Data Analysis and Interpretation

Are you aware of the Nirmal Bharat Abhiyan?

51 responses

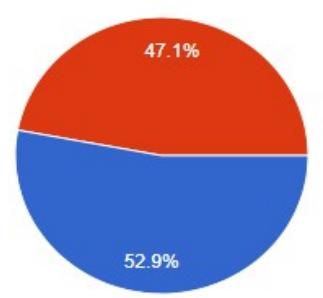

Yes

Interpretation: The above Result shows that 52.9\% people are aware about nirmal bharat abhiyan and the rest were unaware about it.

\section{Are you aware of the Swachh Bharat Abhiyan?}

51 responses

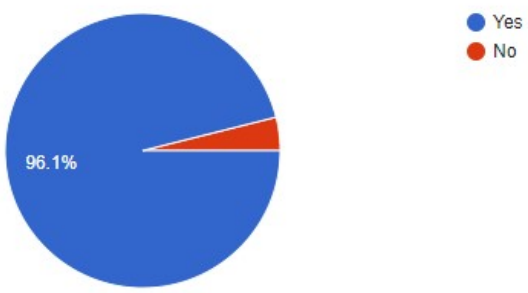

Interpretation: The above Result shows $96.1 \%$ people are aware about swachh bharat abhiyan.

Are you interested in contributing to the Swachh Bharat Abhiyan? 51 responses

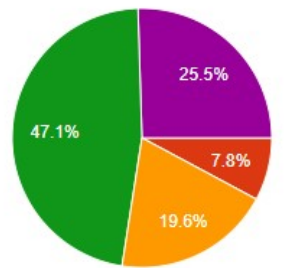

- Strongly Disagree

- Disagree

Neutra

- Agree

Strongly Agree

Interpretation: According to our survey $25.5 \%$ strongly Agree, 47.1\% Agree, 19.6\% Neutal, 7.8\% disagree to show contribution to Swachh Bharat Abhiyan.

Is 24 hour water available in /for the toilet?

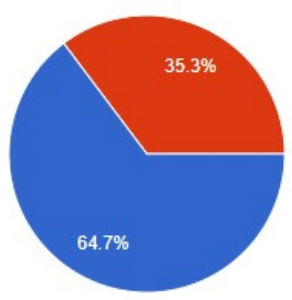


Interpretation: The water facility is 24 hours in the residence according to $64.7 \%$ of the people who have been surveyed.

Do you prefer using Public Toilet?

51 responses

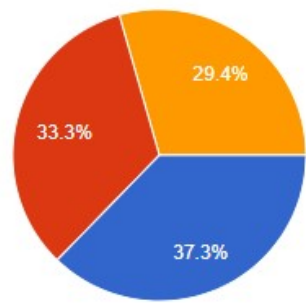

Interpretation: $37.3 \%$ prefer using public toilets whereas $33.3 \%$ disagree with it and some are on the neutral side.

Is there any Open Defecation spot /excreta in an open place?

51 responses

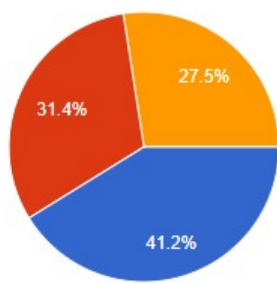

Yes

No

Don't know

Interpretation: $41.2 \%$ have given a positive outlook whereas $31.4 \%$ disagree.

Do you still find plastic being used at around you in market instead of a eco friendly bag

51 responses
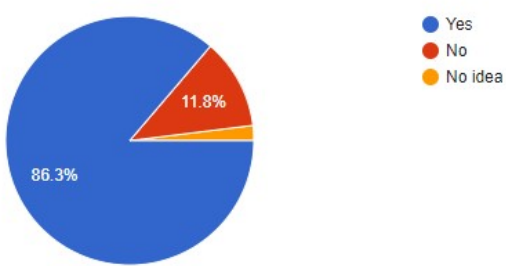

Interpretation: Recently the government has banned plastics but still $86.3 \%$ have noticed of plastic still been used.

Are you using plastic bags instead of eco friendly bags ? 51 responses
Interpretation: $49 \%$ people use plastic bags where as $51 \%$ show a positive response and are using eco friendly bags instead of plastic.

Do you know about the Swachh Bharat Abhiyan app? 51 responses

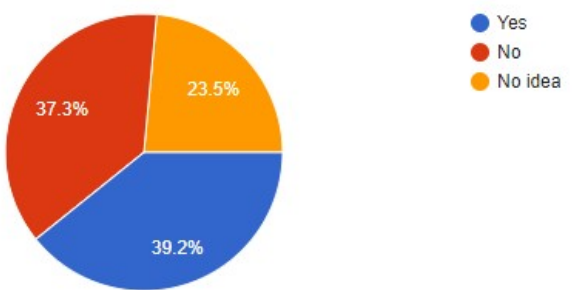

Interpretation: swachh bharat app can also be used to directly connect with the 'safai karamcharwala' to keep their surroundings clean yet $37.7 \%$ and $23.5 \%$ are not using and have no knowledge of it.

Have you used the Swachh Bharat Abhiyan app?

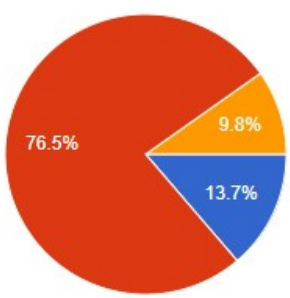

Yes

No

No idea

Interpretation: $76.5 \%$ do not use the SBA app but $13.7 \%$ have used the SBA.

Do you think that hoarding and advertisment are enough to spread the awarness about Swachh Bharat Abhiyan?

51 responses

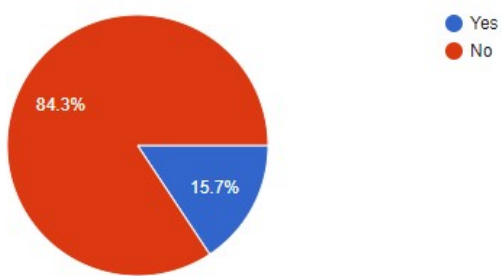

Interpretation: $84.3 \%$ still think that hoarding and advertisement are just not enough to create awareness among the people.

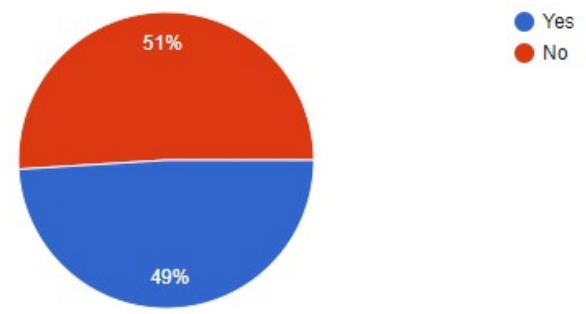


Do you know about wet or dry garbage 51 responses

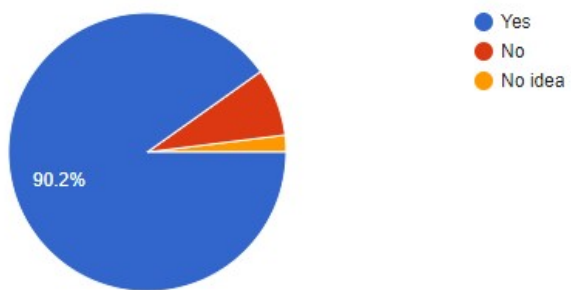

Interpretation: $90.2 \%$ have knowledge about wet or dry garbage. Managing separate dry or wet waste is mandatory for recycling purpose.

At home do you maintain separate Wet and Dry Garbage? 51 responses

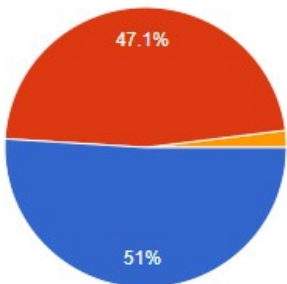

Yes No

Interpretation: Even after $90 \%$ people having knowledge about wet and dry waste people still do not maintain separate dustbins. $47.1 \%$ still do not use separate dustbins whereas $51 \%$ use separate dustbins.

Do you find less littering on road?

51 responses

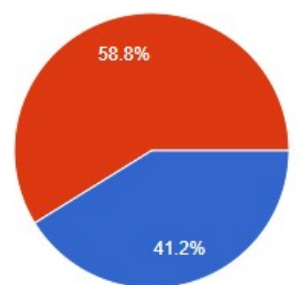

Yes

Interpretation: $41.2 \%$ find less littering on road whereas 58.8\% find more littering in their surroundings.

In your perception would the swatch Bharat Abhiyan change the mindset of the people?

51 responses
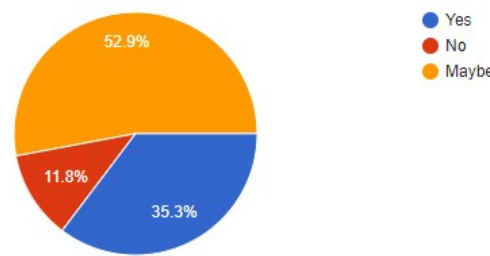

Interpretation: only $35.3 \%$ agree that SBA has change the mindset of the people. Whereas $52.9 \%$ are hoping that SBA might change the mindset of the people. $11.8 \%$ still disagree.
Rate the cleanliness of the public toilets in your area.

51 responses

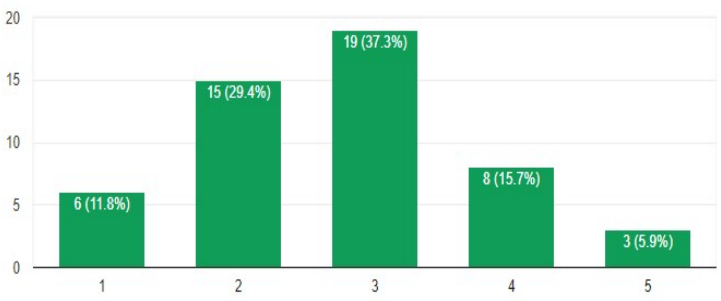

Interpretation: The above histogram shows the cleanliness of public toilets which has 19 people have rated it 3 which is average and 15 people have rated as below average. Only 3 people have rated as excellent.

\section{Result and discussion}

This chapter analyses the responses given by the locals of thane district through the administration of structured questionnaire conducted. In order to make interpretation and analysis easier, tables are presented using Chi-Square test for the above analyzed data.

Table I

\begin{tabular}{|c|c|c|}
\hline Usage of SBA & Count & Percentage \\
\hline $\begin{array}{c}\text { Strongly } \\
\text { Disagree }\end{array}$ & 1 & $1 \%$ \\
\hline Agree & 24 & $24 \%$ \\
\hline Disagree & 3 & $3 \%$ \\
\hline Neutral & 10 & $10 \%$ \\
\hline Strongly Agree & 13 & $13 \%$ \\
\hline Total & 51 & $100 \%$ \\
\hline
\end{tabular}

Table I represents usage of SBA interview on various areas from thane district.

Table II

\begin{tabular}{|c|c|c|}
\hline Awareness of SBA & Count & Percentage \\
\hline Yes & 48 & $48 \%$ \\
\hline No & 2 & $2 \%$ \\
\hline Total & 51 & $100 \%$ \\
\hline
\end{tabular}

Table II represents the awareness of SBA. Out of these, $48 \%$ represent people who are aware of SBA. 
International Journal of Trend in Scientific Research and Development (IJTSRD) ISSN: 2456-6470

Table III

\begin{tabular}{|l|l|l|}
\hline Rate of Cleanliness & Count & Percentage \\
\hline 1 & 6 & $6 \%$ \\
\hline 2 & 15 & $15 \%$ \\
\hline 3 & 19 & $19 \%$ \\
\hline 4 & 8 & $8 \%$ \\
\hline 5 & 3 & $3 \%$ \\
\hline Total & 51 & $100 \%$ \\
\hline
\end{tabular}

Table III represents the rate of cleanliness with respect to their public area who are interested to Contribute for SBA.

\section{Conclusion:}

1. It is necessary to educate young children to make cleanliness as habit and not a responsibility.

2. People should use the SBA app to complain or inform about any garbage or litter in surrounding areas.

3. Heavy fine should be demanded from the people who litter or spit in public areas.

If these points are followed by people then there might be 'Acche Din' very soon.

\section{Reference:}

1. https://www.researchgate.net/profile/Aparna_Nay ak/publication/280939151_Clean_India/links/560 433ab08aeb5718feee475.pdf

2. http://questforequity.org/contents/Papers/No\%20S wachh $\% 20$ Bharat $\% 20$ without $\% 20$ Annihilation $\% 2$ 0of $\% 20$ Caste.pdf
3. https://en.wikipedia.org/wiki/Swachh_Bharat_Ab hiyan

4. http://www.swachhbharaturban.in/sbm/home/

5. https://www.indexmundi.com/india/demographics _profile.html

6. https://www.researchgate.net/publication/2792018 08_Swachh_Bharat_Mission_A_Step_towards_En vironmental_Protection

7. http://www.indiacelebrating.com/essay/swachhbharat-abhiyan-essay/

8. https://www.readycleaningserviceskc.com/singlepost/2016/05/28/Cleaning-and-Organizing-is-aPractice-Not-a-Project

9. https://timesofindia.indiatimes.com/city/thane/min dset-change-is-the-key-to-cleancampaign/articleshow/61520562.cms

10. https://timesofindia.indiatimes.com/city/mumbai/s wachh-ranking-navi-mumbai-in-top-10-big-leapsfor-mum-and-thane/articleshow/64716990.cms

11. https://www.livemint.com/Politics/wLpq03qE6gk VL9FlCQMzgL/Govt-asks-radio-stations-TVchannels-to-boost-Swachhta-Hi-S.html

12. https://www.slideshare.net/AnirudhMehta24/empi rical-study-on-measuring-attitude-and-perceptionof-people-towards-swachh-bharat-abhiyan

13. https://www.slideshare.net/aditieedeshpande/busin ess-research-methods-project

14. https://www.hindustantimes.com/mumbainews/thane-clean-up-drive-to-end-on-a-highnote/story-hEcwcMQQ0oMkQ8UwysUdRL.html 